\title{
Maistui netinkamų riebalinių žaliavų panaudojimas biodyzelino gamyboje
}

Eglè Sendžikienė,

Milda Gumbytè

Aleksandro Stulginskio universitetas, Studentu g. 11,

LT-53361 Akademija, Kauno r.

El.paštas egle.sendzikiene@asu.lt
Biodegalų gamyba iš maistinių sèklų turi neigiamus ekonominius, socialinius ir aplinkosauginius efektus, todèl būtina ieškoti alternatyvių žaliavų, tinkančių biodyzelino gamybai. Riebalinėms atliekoms, kurios tinka biodyzelino gamybai, galima priskirti gyvūninės kilmès riebalus, susidarančius perdirbant mėsą ir pieną, kailių ir odų apdorojimo riebalines atliekas. Biodegalu gamybai tikslinga naudoti ir aliejinguosius augalus, kurių aliejus neatitinka maistiniam aliejui keliamų reikalavimų. Šio darbo tikslas - ištirti gyvūninès kilmès riebalų ir judrų (Camelina sativa) sèklų aliejaus mišinių panaudojimo biodyzelino gamyboje galimybes taikant biotechnologinius metodus peresterinimui naudojant butanolį. Gaminant judrų aliejaus ir gyvūninès kilmės riebalų rūgščių butilesterius (JRBE) santykiu 1:3, efektyvus biokatalizatorius - Lipozyme TL IM. Dviejų stadijų proceso optimalios sąlygos: pirma stadija - $9 \%$ lipazès (aliejaus masės), aliejaus ir butanolio molinis santykis $-1: 6$, temperatūra $-40{ }^{\circ} \mathrm{C}$, trukmè -6 val.; antra stadija $-5 \%$ lipazès, aliejaus ir butanolio molinis santykis $-1: 8$, temperatūra $-40^{\circ} \mathrm{C}$, sintezès trukmè -6 val. JRBE atitinka mūsų šalyje naudojamiems degalams keliamus reikalavimus, i butilesterius ịterpus antioksidanto Ionol BF200 (1 000 ppm) ir depresanto Chimec 6635 (2 $000 \mathrm{ppm}$ ) priedus.

Raktažodžiai: biodyzelinas, judrų aliejus, riebalai, biokatalizatorius, butanolis

\section{IVADAS}

Europos Sąungos (ES) direktyva (2009/28/EB) numato, kad iki $2020 \mathrm{~m}$. transporte minimalus privalomas sunaudoti biodegalų kiekis, kurị turètų pasiekti kiekviena valstybė naré, turètų būti $10 \%$. Biodegalai dyzeliniams varikliams ES šalyse daugiausia gaminami iš rapsų aliejaus. Intensyviai plečiantis biodyzelino gamybai, nuolat didejja jo gamybos žaliavos - rapsų sèklų - poreikis. Dar viena problema, susijusi su biodyzelino gamybos pletra, yra tai, kad kaip gamybos žaliava naudojamas maistui tinkantis rapsų aliejus. Todẻl svarbu ieškoti galimybių biodyzelino gamybai panaudoti nemaistines žaliavas. Riebalinėms atliekoms, kurios tinka biodyzelino gamybai, galima priskirti gyvūninès kilmès riebalus, susidarančius perdirbant mėsą ir pieną, kailių ir odų apdorojimo riebalines atliekas, kritusių gyvulių ir skerdyklų atliekas. Biodegalų gamybai taip pat tikslinga naudoti aliejinguosius augalus, kurių aliejus nemažina maisto žaliavų po- tencialo. Tai galètų būti vasarinès judros, kurias galima naudoti sejjomainai ir kaip issèli grūdiniams augalams. Aliejingujų augalų sèklos po pjūties reikalauja greito apdorojimo (1-1,5 paros), ypač nepalankiomis oro sąlygomis. Pavèlavus vyksta aliejaus hidrolizè, didejja jo rūgštingumas ir jis nebetinka maistinio aliejaus gamybai. Ypač greitai hidrolizuojasi aliejai, turintys dideli polinesočiųjų rūgščių kiekí, o šiai kategorijai priklauso judrų aliejus. Todèl netinkamas maistui aliejus galètų būti naudojamas biodyzelino gamybai. Tačiau naujų rūšių aliejaus panaudojimas biodyzelino gamyboje kelia kai kurių problemų. Judrų aliejus turi per didelị linoleno rūgšties (C 18:3) kiekị (Peiretti, Meineri, 2007; Berti et al., 2011), kuris biodyzelino kokybę apibrèžiančiame standarte EN 14214 apribotas iki 12 \%, o judrų aliejuje šios rūgšties kiekis siekia 43,5 \%. Didelę reikšmę biodegalų kokybei turi jų atsparumas oksidacijai. Oksidacijos greitị didina mono- ir polinesočiųju riebalų rūgščių kiekis degaluose. Judrų aliejus turi 
per 85 \% nesočiųjų riebalų rūgščių (C 18:1, C 18:2, C 18:3, C 20:1) (Vollmann, 2007), todèl iš jo gautų esterių atsparumas oksidacijai turètų būti nedidelis. Judrų aliejaus esterių jodo skaičius siekia $144 \mathrm{~g} / 100 \mathrm{~g}$ produkto ir yra didesnis nei standarte nurodoma didžiausia vertė $\left(120 \mathrm{~g} \mathrm{I}_{2} / 100 \mathrm{~g}\right)$. Nustatyta, kad žemą jodo skaičių (52 g $\mathrm{I}_{2} / 100 \mathrm{~g}$ ) turi gyvūninès kilmès riebalai (Sendžikiené, 2005), tai patvirtina ir užsienio mokslininkų tyrimai (Tashtoush et al., 2004). Todèl biodyzelino gamybai naudojami gyvūninès kilmès riebalų ir judrų aliejaus mišiniai juos peresterinant metanoliu ir naudojant cheminius rūgštinius arba šarminius katalizatorius (Tianwei Tan et al., 2009).

Vienas iš naujesnių ir aktualesnių biodyzelino gavimo būdų - biokatalizè kaip katalizatorius naudojant fermentinius preparatus. Nors biotechnologiniai metodai šiuo metu yra labai svarbūs ir aktualūs, kol kas vykdant biodyzelino biosintezę negauta rezultatų, leidžiančių toki procesą diegti gamyboje. Pagrindine priežastis yra ta, kad peresterinimui naudojamas metanolis inaktyvuoja lipazes (Shimada et al., 1999; Shimada et al., 2002). Kitų alkoholių panaudojimas mažai tirtas, atlikti tik epizodiniai biokatalizès tyrimai, peresterinimui naudojant etanolį, izopropanolį, izobutanoli (Antczak et al., 2009). Biodyzelino gamyboje metanoli tikslinga pakeisti butanoliu, kuris mažiau slopina lipazes, todèl galima būtų naudoti didesnị jo kiekị. Be to, šiuo alkoholiu pakeičiant sintetinị, iš gamtinių dujų išgaunamą metanolị, biodyzelinas būtų gaminamas tik iš atsinaujinančių energijos išteklių, nes butanolis gali būti gaunamas iš biomasès taikant fermentavimo metodus (Pfromm et al., 2010). Tokiu būdu gauti biodegalai būtų visiškai atsinaujinantys ir tausojantys aplinką.

Šio darbo tikslas - ištirti gyvūninès kilmès riebalų ir judrų aliejaus mišinių panaudojimo biodyzelino gamyboje galimybes, taikant biotechnologinius metodus peresterinimui naudojant butanolị.

\section{TYRIMŲ METODAI IR SĄLYGOS}

\section{Efektyvaus biokatalizatoriaus parinkimas}

Biodyzelino sintezès ir katalizatoriaus parinkimo tyrimai atlikti kūginèje kolboje, kuri buvo sujungta su šaldytuvu, termometru su temperatūros matuokliu ir maišykle (pastoviu sūkių dažniu $200 \mathrm{~min}^{-1}$ ). I kolbą ịpilamas reikiamas aliejaus ir riebalų mišinio kiekis (50 ml), nuolatos maišoma ir termostatuoja- ma. Judrų sẻklos gautos iš Lietuvos agrarinių ir miškų mokslų centro Vèžaičių filialo, aliejus išspaustas laboratoriniu presu VARMEC RCV 252.

Mišiniui pašilus iki reikiamos $40{ }^{\circ} \mathrm{C}$ temperatūros, ipilama butanolio $(99,5 \%$ grynumo, Chempur) ir pridedama katalizatoriaus. Pradineje stadijoje, siekiant parinkti efektyviausią biokatalizatorių aliejaus ir riebalų mišini peresterinimo butanoliu procesui, tirtos pramoninès lipazès: Novozyme 435, Lipozyme TL IM, Lipozyme RM IM ir eksperimentinès UAB „Biocentras“, Lipase Ps. mend. ir Lipozyme TL 100L. Tyrimai atliekami esant vienodoms sąlygoms: $40{ }^{\circ} \mathrm{C}$ temperatūroje, naudojant $5 \%$ fermento (nuo aliejaus kiekio), esant butanolio ir aliejaus bei riebalų mišinio moliniam santykiui 3:1 ir 5 val. reakcijos trukmei.

Pasibaigus sintezès procesui, mèginiai filtruojami, plaunami vandeniu ir vakuuminio rotacinio išgarintuvo pagalba (temperatūra $-90{ }^{\circ} \mathrm{C}$, vakuumas - 30 mbar) pašalinamas vanduo ir perteklinis butanolis. Gauti rapsu aliejaus butilesteriai (RRBE) analizuoti plonasluoksnès chromatografijos metodu. $50 \mu \mathrm{l}$ esterių buvo ištirpinami $500 \mu \mathrm{l}$ dietileteryje, gautas mišinys homogenizuotas. $2 \mu \mathrm{l}$ paruošto mišinio švirkštu užlašinama ant boru impregnuotų silikagelio G-25 plokštelių (sluoksnio storis $0,25 \mathrm{~mm}$ ). Kontrolei naudoti tokiu pat būdu paruošti rapsų aliejaus, rapsų aliejaus metilesterių ir riebalų rūgščių monogliceridų tirpalai dietileteryje. Po to plokštelès įmerkiamos i tirpiklių (petrolio eteris, dietileteris, acto rūgštis, sumaišyti atitinkamai 70:30:1 tūrio dalimis) sistemą ir laikoma tol, kol eliuentas pasieks apie $1-1,5 \mathrm{~cm}$ iki plokštelių viršaus. Tada plokšstelès išimamos, džiovinamos ir ryškinamos jodo garuose. Analizuojant tirtụjų mėginių dèmès lygintos su kontrolès dėmėmis (buvo atsižvelgiama ị dèmés padètị, ryškumą ir jos plotą).

\section{Biodyzelino sintezè}

Optimalioms biotechnologinèms sintezès sąlygoms nustatyti atlikti eksperimentai keičiant temperatūrą (nuo 20 iki $50{ }^{\circ} \mathrm{C}$ ), biokatalizatoriaus kieki (nuo 3 iki $15 \%$ ), aliejaus riebalu mišinio ir butanolio molini santyki (nuo 3 iki 12) ir sintezès trukmę (nuo 2 iki 8 val.).

\section{Riebalų rūgščių butilesterių fizikinès ir cheminès savybès}

Riebalų rūgščių butilesterių (RRBE) kokybès rodikliai nustatyti taikant standartuose LST EN 14214 
(LST EN 14214) ir LST EN 590 (LST EN 590) nurodytus tyrimų metodus. Atsižvelgiant $\mathfrak{i}$ tai, kad pradiniuose optimalių butilesterių sintezès sąlygu tyrimuose esteriu kiekis buvo nedidelis, jis vertintas pagal gliceridų kieki mėginyje. Gliceridai (glicerolis, monogliceridai, digliceridai ir trigliceridai) analizuoti dujiniu chromatografu Perkin Elmer Clarus 500 (detektorius - FID, kolonèle - Restek MXTBiodiesel TG $(0,15 \mathrm{~m},-0,32 \mathrm{~mm}-0,10 \mu \mathrm{m})$ pagal standartą LST EN 14105 (Sendzikiene et al., 2016).

Esant didesniam kaip 80 \% esterių kiekiui biodyzeline, jiems nustatyti taikytas standarte LST EN 14103 (LST EN 14103) nurodytas dujinès chromatografijos metodas, analizuota dujiniu chromatografu Perkin Elmer Clarus 500 (detektorius - FID) su kapiliarine kolonèle Alltech ATFAME $(30 \mathrm{~m}-0,25 \mathrm{~mm}-0,25 \mu \mathrm{m})$. Dujų nešèjo (vandenilio) srautas pastovus, $3 \mathrm{ml} / \mathrm{min}$.

Atsparumas oksidacijai, esant $110{ }^{\circ} \mathrm{C}$ temperatūrai, nustatomas prietaisu RANCIMAT 743 pagal LST EN 14112 (LST EN 14112) standartą. Mèginio masè $-3 \pm 0,001 \mathrm{~g}$, prapučiamo oro srautas $-101 \mathrm{~h}^{-1}$. Atsparumui oksidacijai padidinti nau- doti antioksidantai: Kerobit, Irganox L 107, Baynox, Ionol.

RFT (ribinè filtruojamumo temperatūra) testams atlikti naudota termostatinè vonele PROLINE RP-845 (LAUDA, Vokietija). Degalų mišinių ribinè filtruojamumo temperatūra (RFT) nustatyta pagal standarto LST EN116 (LST EN116) reikalavimus. Žematemperatūrinèms savybèms pagerinti naudoti depresantai: Infenium 485, Viscoplex 10 305, Chimec 6635.

\section{TYRIMŲ REZULTATAI IR JŲ APTARIMAS}

\section{Efektyvaus biokatalizatoriaus parinkimas}

Ivertinus gyvūninès kilmès riebalų ir judrų mišinių linoleno rūgšties kiekị ir jodo skaičių, biodyzelino gamybai naudotas judrų sẻklų aliejaus ir gyvūninès kilmès riebalų mišinys masès santykiu 1:3. Pirmajame etape parinktas efektyviausias biokatalizatorius, peresterinimui naudojant butanoli.

Kaip matyti iš pateiktos chromatogramos (1 pav.), naudojant lipazes UAB „Biocentras“ ir

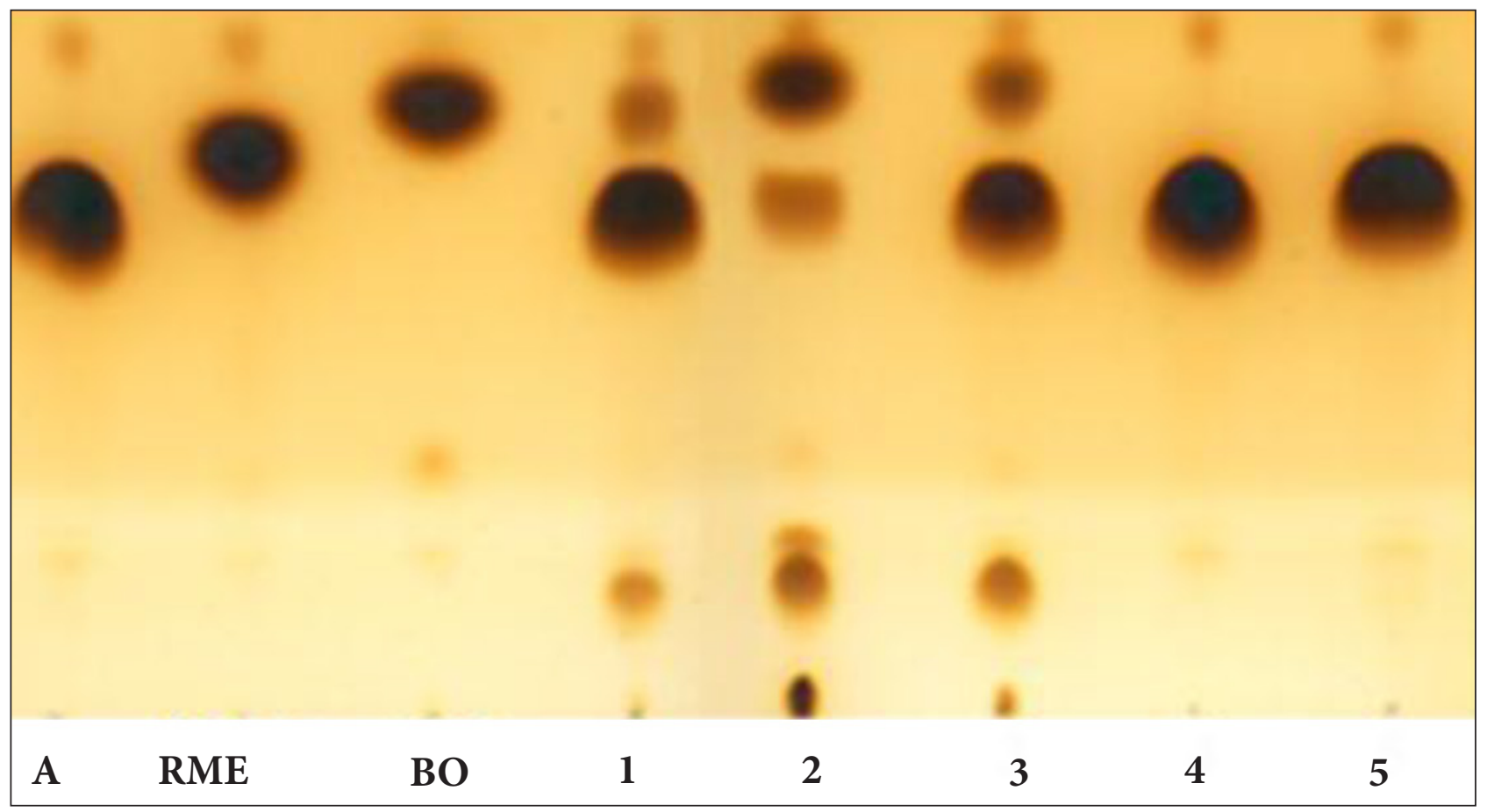

1 pav. Lipazių efektyvumas judrų aliejaus ir gyvūninès kilmės riebalų (1:3) butilesterių sintezèje: A - rapsų aliejus, RME - rapsų aliejaus metilesteriai, BO - butiloleatas, katalizatoriumi naudojant: Novozym 435 (1), Lipozyme TL IM (2), Lipozyme RM IM (3), lipazė UAB „Biocentras“ (4) ir lipazė Lipase Ps. mend (5)

Fig. 1. The efficiency of lipases in the synthesis of camelina oil and animal fat (1:3) butyl esters: A is rapeseed oil, RME is methyl esters of rapeseed oil, and BO is butyl oleate. Used catalysts: Novozym 435 (1), Lipozyme TL IM (2), Lipozyme RM IM (3), lipase JSC Biocentras (4), and lipase Lipase Ps. mend (5) 
Lipase Ps. mend, butilesteriai beveik nesusidarè. Sintezę katalizuojant likusiais fermentais, judrų aliejaus ir gyvūninès kilmès riebalų (1:3) butilesteriai (JRBE) susidaro, tačiau lieka ir nesureagavusio aliejaus. Pagal efektyvumą lipazes galima išdèstyti tokia tvarka (link efektyviausio fermentinio preparato): Novozym 435, Lipozyme RM IM ir Lipozyme TL IM (pats efektyviausias). Taigi, tolimesniems tyrimams buvo pasirinktas fermentas Lipozyme TL IM.

\section{Optimalių proceso sąlygu parinkimas}

Pradiniame etape, siekiant nustatyti optimalias peresterinimo butanoliu sąlygas, parinktą proceso temperatūrą keičiant nuo 20 iki $50{ }^{\circ} \mathrm{C}$, kiti rodikliai išliko nepakitę: fermento Lipozyme TL IM kiekis - $5 \%$ (nuo aliejaus riebalų kiekio); alkoholio (butanolio) ir aliejaus molinis santykis - 3:1; reakcijos trukmè - 5 val. Gauti duomenys pateikti 2 pav.

Iš gautų duomenų matyti (2 pav.), kad keliant temperatūrą iki $40{ }^{\circ} \mathrm{C}$ peresterinimo laipsnis didejja, o toliau didinant nežymiai mažèja. Galima daryti prielaidą, kad esant aukštesnei temperatūrai prasideda biokatalizatoriaus inaktyvacija. Iš gautų duomenų aišku, kad optimali proceso temperatūra yra $40{ }^{\circ} \mathrm{C}$, tai patvirtina ir kiti mokslininkai, tyrę biosintezę. Jie teigia, kad optimali peresterinimo proceso temperatūra naudojant biokatalizatorius yra $30-55^{\circ} \mathrm{C}$ (Iso et al., 2001; Haas et al., 2002).

Nustačius optimalią temperatūrą buvo atlikti eksperimentai keičiant kitas sąlygas, darančias itaką biodyzelino išeigai: biokatalizatoriaus kieki (nuo 3 iki $15 \%$ ), aliejaus ir riebalų mišinio bei butanolio molini santyki (nuo 3 iki 12) ir sintezès trukmę (nuo 2 iki 8 val.), esant $40^{\circ} \mathrm{C}$ temperatūrai.

3 pav. pavaizduota peresterinimo laipsnio priklausomybè nuo katalizatoriaus kiekio ir žaliavu molinio santykio. Iš pateiktų duomenų matyti, kad, didejjant lipazès kiekiui ir žaliavų moliniam santykiui, dideja ir esterio kiekis, maksimalus peresterinimo laipsnis (91-92 \%) gaunamas, kai žaliavų molinis santykis didesnis nei 8 ir lipazès kiekis yra didesnis kaip $13 \%$. Tačiau peresterinimo laipsnis neatitinka standarto reikalavimų, yra mažesnis kaip 96,5 \%. Šią problemą išspręsti galima gautą produktą peresterinant pakartotinai, t. y. biodyzelino sintezeje taikant dviejų stadijų peresterinimo procesą. Ištyrus proceso trukmès įtaką, siekiant naudoti kuo mažiau biokatalizatoriaus, nustatytos optimalios pirmos stadijos sąlygos: $9 \%$ lipazès (aliejaus masès), aliejaus ir riebalų mišinio

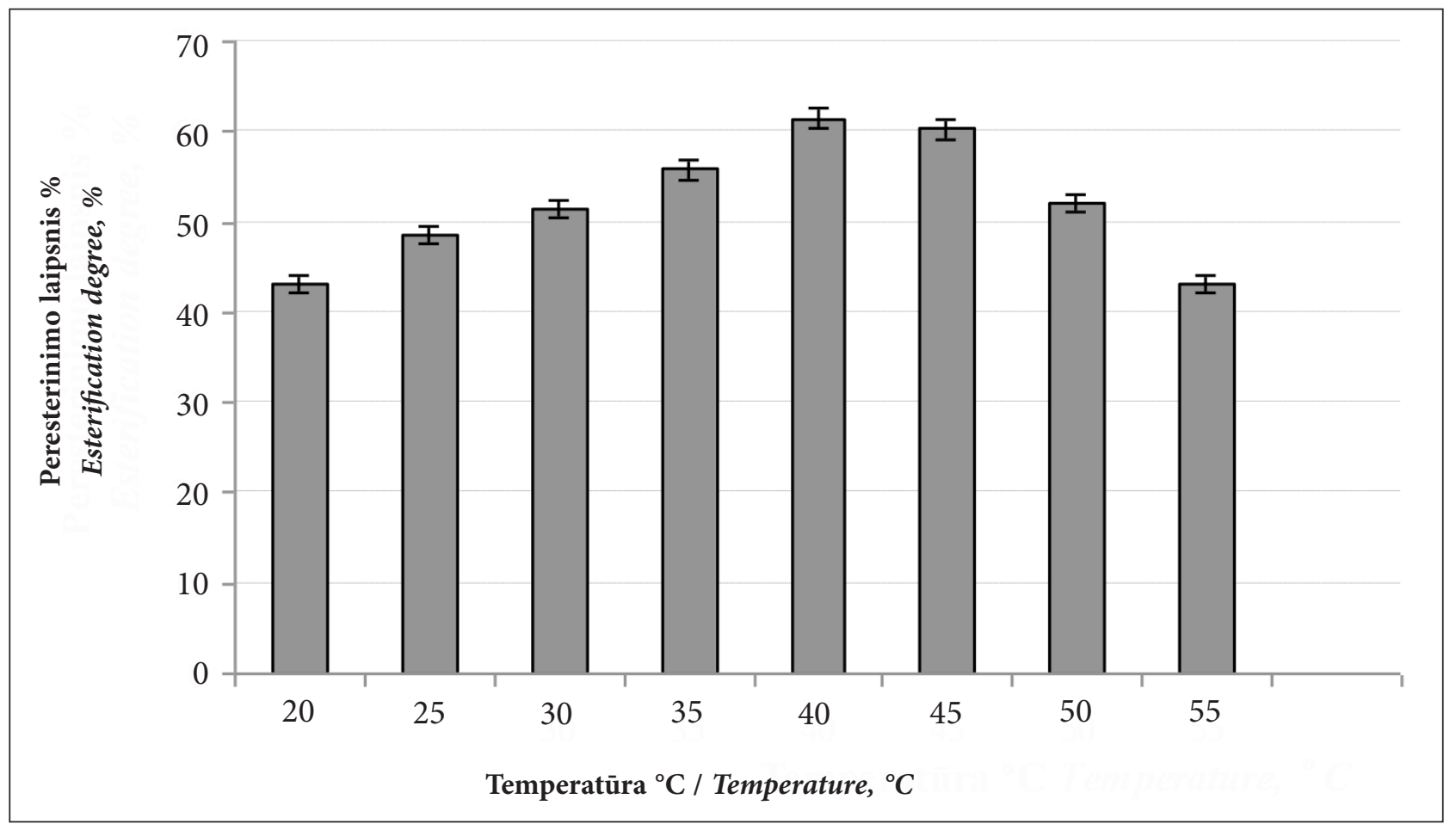

2 pav. Judrų aliejaus ir gyvūninès kilmès riebalų (1:3) peresterinimo laipsnio priklausomybė nuo temperatūros Fig. 2. The dependence of camelina oil and animal fat (1:3) butyl esters esterification degree on temperature 


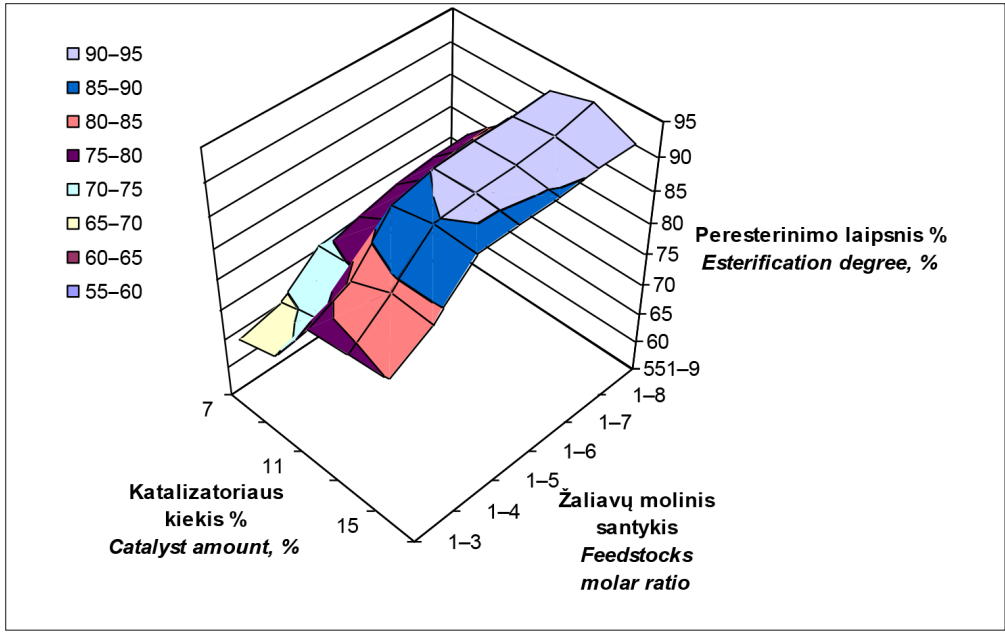

3 pav. Peresterinimo laipsnio priklausomybè nuo katalizatoriaus kiekio, judru aliejaus ir gyvūninès kilmès riebalų mišinio (1:3) bei butanolio molinio santykio (1 stadija)

Fig. 3. The dependence of esterification degree on the amount of catalyst and the molar ratio of camelina oil and animal fat mixture (1:3) and butanol (step 1) bei butanolio molinis santykis - 1:6, temperatūra $-40{ }^{\circ} \mathrm{C}$, trukmé -6 val. Pirmos stadijos metu gaunama $78,5 \%$ JRBE.

Toliau tyrimams naudotas pirmos peresterinimo stadijos produktas, kuriame buvo 79,2\% JRBE. Peresterinimo procesas vykdytas esant $40{ }^{\circ} \mathrm{C}$ temperatūrai, keičiant žaliavų ir butanolio molini santyki (nuo 1:4 iki 1:10), katalizatoriaus kiekị (nuo 3 iki $9 \%$ ), trukmę (nuo 2 iki 8 val.). Atlikus tyrimus nustatyta, kad efektyviausiai peresterinimas vyksta pirmas 6 valandas.

Nustatyta (4 pav.), kad didesnis nei $96,5 \%$ peresterinimo laipsnis gaunamas tuo atveju, kai lipazès kiekis yra didesnis kaip $5 \%$, o žaliavų molinis santykis yra didesnis kaip 1:8 arba tuo atveju, kai lipazès kiekis viršija $7 \%$, o žaliavų molinis santykis - 1:6. Po peresterinimo perteklinis butanolis distiliuojamas ir gali būti grąžinamas ị procesą. Biokatalizatorius - lipazè taip pat gali būti naudojama pakartotinai, tačiau jos regeneravimas reikalauja didesnių energijos ir materialinių sąnaudų, todèl tikslinga rinktis sąlygas, kurioms esant reikalingas mažesnis biokatalizatoriaus kiekis. Galima teigti, kad optimalios antros peresterinimo stadijos sąlygos yra šios: 5 \% lipazès, aliejaus ir butanolio molinis santykis $-1: 8$, temperatūra $-40^{\circ} \mathrm{C}$, sintezès trukmè - 6 val.

\section{Riebalų rūgščių butilesterių fizikinès ir cheminès savybès}

Siekiant nustatyti, kaip gautų produktų fizikinès ir cheminès savybès atitinka standarto EN 14214 reikalavimus, ir palyginti su iprastinio biodyzelino - rapsų aliejaus metilesterių (RME) - atitinkamomis savybemis, buvo ịvertintos judrų aliejaus ir gyvūninès kilmès riebalų (1:3) butilesterių (JRBE) fizikinès bei cheminès savybès. Duomenys pateikti 1 lentelèje.

JRBE - judrų aliejaus ir gyvūninès kilmès riebalų (1:3) butilesteriai (camelina oil and animal fat (1:3) butylesters).

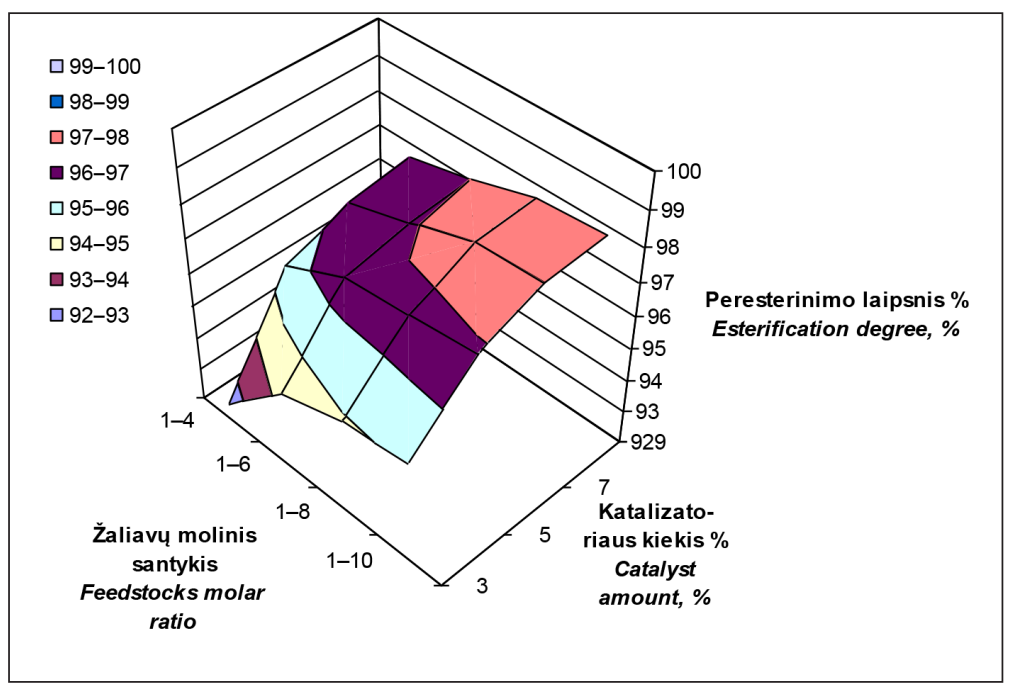

4 pav. Peresterinimo laipsnio priklausomybè nuo katalizatoriaus kiekio ir žaliavų molinio santykio antroje peresterinimo stadijoje

Fig. 4. The dependence of esterification degree on the amount of catalyst and feedstock molar ratio (step 2) 
Kaip matyti iš 1 lentelèje pateiktų duomenų, JRBE beveik visomis fizikinèmis ir cheminemis savybėmis atitinka standarto EN 14214 reikalavimus, išskyrus atsparumą oksidacijai ir ribinę filtruojamumo temperatūrą. Atsparumą oksidacijai galima būtų padidinti pridèjus antioksidantų, $\mathrm{o}$ ribinę filtruojamumo temperatūrą - pridejjus depresantų.
Atsparumas oksidacijai yra viena iš svarbesnių biodyzelino savybių. Biodyzelino autooksidacija vyksta biodyzelino saugojimo laikotarpiu, kai esteriai kontaktuoja su deguonimi, formuodami peroksidus, aldehidus, karboksilines rūgštis (Karavalakis et al., 2010). Šios medžiagos gali neigiamai paveikti variklio darbą: blokuoti filtrus ir purkštukus bei formuoti korozingą aplinką kuro ipurškimo

1 lentelè. Riebalų rūgščių butilesterių fizikinès cheminès savybès

Table 1. The physical and chemical properties of butyl esters

\begin{tabular}{|c|c|c|c|c|}
\hline \multirow{2}{*}{$\begin{array}{l}\text { Rodiklis } \\
\text { Parameter }\end{array}$} & \multicolumn{2}{|c|}{$\begin{array}{l}\text { Standarto EN } 14214 \text { reikalavimai } \\
\text { EN } 14214 \text { requirements }\end{array}$} & \multirow[t]{2}{*}{ RME } & \multirow[t]{2}{*}{ JRBE } \\
\hline & $\min$ & $\max$ & & \\
\hline $\begin{array}{l}\text { Esterių kiekis \% } \\
\text { Ester content, \% }\end{array}$ & 96,5 & - & 97,0 & 96,7 \\
\hline $\begin{array}{l}\text { Tankis esant } 15^{\circ} \mathrm{C} \mathrm{kg} / \mathrm{m}^{3} \\
\text { Density at } 15^{\circ} \mathrm{C}, \mathrm{kg} / \mathrm{m}^{3}\end{array}$ & 860 & 900 & 875 & 883 \\
\hline $\begin{array}{l}\text { Klampa esant } 40^{\circ} \mathrm{C} \mathrm{mm}^{2} / \mathrm{s} \\
\text { Viscosity at } 40^{\circ} \mathrm{C}, \mathrm{mm}^{2} / \mathrm{s}\end{array}$ & 3,50 & 5,00 & 4,6 & 4,4 \\
\hline $\begin{array}{l}\text { Sieros kiekis } \mathrm{mg} / \mathrm{kg} \\
\text { Sulfur content, } m g / \mathrm{kg}\end{array}$ & - & 10 & 5 & 4 \\
\hline $\begin{array}{l}\text { Monogliceridu kiekis \% } \\
\text { Monoglyceride content, \% }\end{array}$ & - & 0,70 & 0,49 & 0,52 \\
\hline $\begin{array}{l}\text { Digliceriduc kiekis \% } \\
\text { Diglyceride content, \% }\end{array}$ & - & 0,20 & 0,16 & 0,02 \\
\hline $\begin{array}{l}\text { Trigliceriduc kiekis } \% \\
\text { Triglyceride content, \% }\end{array}$ & - & 0,20 & 0,04 & 0,03 \\
\hline $\begin{array}{l}\text { Laisvojo glicerolio kiekis \% } \\
\text { Free glycerol content, \% }\end{array}$ & - & 0,02 & 0,01 & 0,01 \\
\hline $\begin{array}{l}\text { Bendrojo glicerolio kiekis \% } \\
\text { Total glycerol content, \% }\end{array}$ & - & 0,25 & 0,2 & 0,23 \\
\hline $\begin{array}{l}\text { Cetaninis skaičius } \\
\text { Cetane number }\end{array}$ & 51,0 & - & 54,1 & 58,3 \\
\hline $\begin{array}{l}\text { Rūgščių skaičius mg } \mathrm{KOH} / \mathrm{g} \\
\text { Acid value, } m g \mathrm{KOH} / g\end{array}$ & - & 0,5 & 0,1 & 0,3 \\
\hline $\begin{array}{l}\text { Jodo skaičius } \mathrm{g} \mathrm{J}_{2} / 100 \mathrm{~g} \\
\text { Iodine value, } \mathrm{g} \mathrm{J}_{2} / 100 \mathrm{~g}\end{array}$ & - & 120 & 112 & 78 \\
\hline $\begin{array}{l}\text { Vandens kiekis } \mathrm{mg} / \mathrm{kg} \\
\text { Moisture content, } \mathrm{mg} / \mathrm{kg}\end{array}$ & - & 500 & 150 & 200 \\
\hline $\begin{array}{c}\text { Fosforo kiekis ppm } \\
\text { Phosphorus content, ppm }\end{array}$ & & 10 & 8 & 8 \\
\hline $\begin{array}{l}\left.\text { Vario plokštelès korozija ( } 3 \text { h esant } 50^{\circ} \mathrm{C}\right) \text {, koro- } \\
\text { zijos laipsnis } \\
\text { Copper strip corrosion }\left(3 \text { h at } 50^{\circ} \mathrm{C}\right)\end{array}$ & & & 1 & 1 \\
\hline $\begin{array}{c}\text { Atsparumas oksidacijai esant } 110^{\circ} \mathrm{C} \mathrm{h} \\
\text { Oxidation stability at } 110^{\circ} \mathrm{C}, \mathrm{h}\end{array}$ & 8 & & 6,32 & 3,6 \\
\hline $\begin{array}{l}\text { RFT (ribinè filtruojamumo temperatūra) }{ }^{\circ} \mathrm{C} \\
\quad C F P P \text { (cold filter plugging point), }{ }^{\circ} \mathrm{C}\end{array}$ & $\begin{array}{r}-5^{\circ} \mathrm{C} \\
-26^{\circ} \mathrm{C},-\end{array}$ & $\begin{array}{l}\text { imer) } \\
n \text { winter) }\end{array}$ & -10 & 3 \\
\hline
\end{tabular}

RME - rapsų aliejaus metilesteriai / methyl esters of rapeseed oil. 
i̇rangoje. Be to, biodyzelino būklès blogejjimas dèl autooksidacijos gali daryti ittaką biodegalų savybèms, pavyzdžiui: pliūpsnio temperatūrai, esterio kiekiui, šiluminei vertei, cetaniniam skaičiui, kinematinei klampai ir tankiui, taip pat rūgštingumui (Pullen, Saeed, 2014).

Siekiant padidinti atsparumą oksidacijai buvo tirti antioksidantai Kerobit, Irganox L 107, Ionol BF200, esant ivvairioms jų koncentracijoms JRBE. Gauti rezultatai pateikti 5 pav.

Silpniausiai veike Irganox L 107. Siekiant padidinti JRBE atsparumą oksidacijai iki 8 val., jo koncentracija turi būti $2000 \mathrm{ppm}$. Naudojant 1500 ppm Kerobit, riebalų rūgščių butilesterių atsparumas oksidacijai pasiekia standarto reikalavimus. JRBE atitinka standarto reikalavimus, kai naudojamas antioksidanto Ionol BF200 (1000 ppm) priedas.
Nustatyta, kad gautų JRBE ribinè filtruojamumo temperatūra (RFT) yra $+3{ }^{\circ} \mathrm{C}$, o pagal vasaros periodu naudojamų dyzelinių degalų RFT turi būti ne aukštesnè kaip $-5{ }^{\circ} \mathrm{C}$, žiemos periodu $--32{ }^{\circ} \mathrm{C}$ (LST EN 590). Siekiant sumažinti RFT buvo naudoti depresantai, kurių koncentracija kito nuo 500 iki 4000 ppm. Gauti rezultatai pateikti 2 lenteleje. Pastebèta, kad depresantų, kaip ir antioksidantų, poveikis JRBE nedaug tesiskiria: mažiausiu efektyvumu pasižymi Infenium 485 , esant jo koncentracijai 4000 ppm, esterių mišinio RFT pasiekia tik $0{ }^{\circ} \mathrm{C}$. Efektyviausiai veikia Chimec 6635, kurio $2000 \mathrm{ppm}$ priedas sumažina biodyzelino ribinę filtruojamumo temperatūrą iki $-5{ }^{\circ} \mathrm{C}, \mathrm{t}$. y. tokie degalai mūsų šalyje galètų būti naudojami vasaros laikotarpiu.

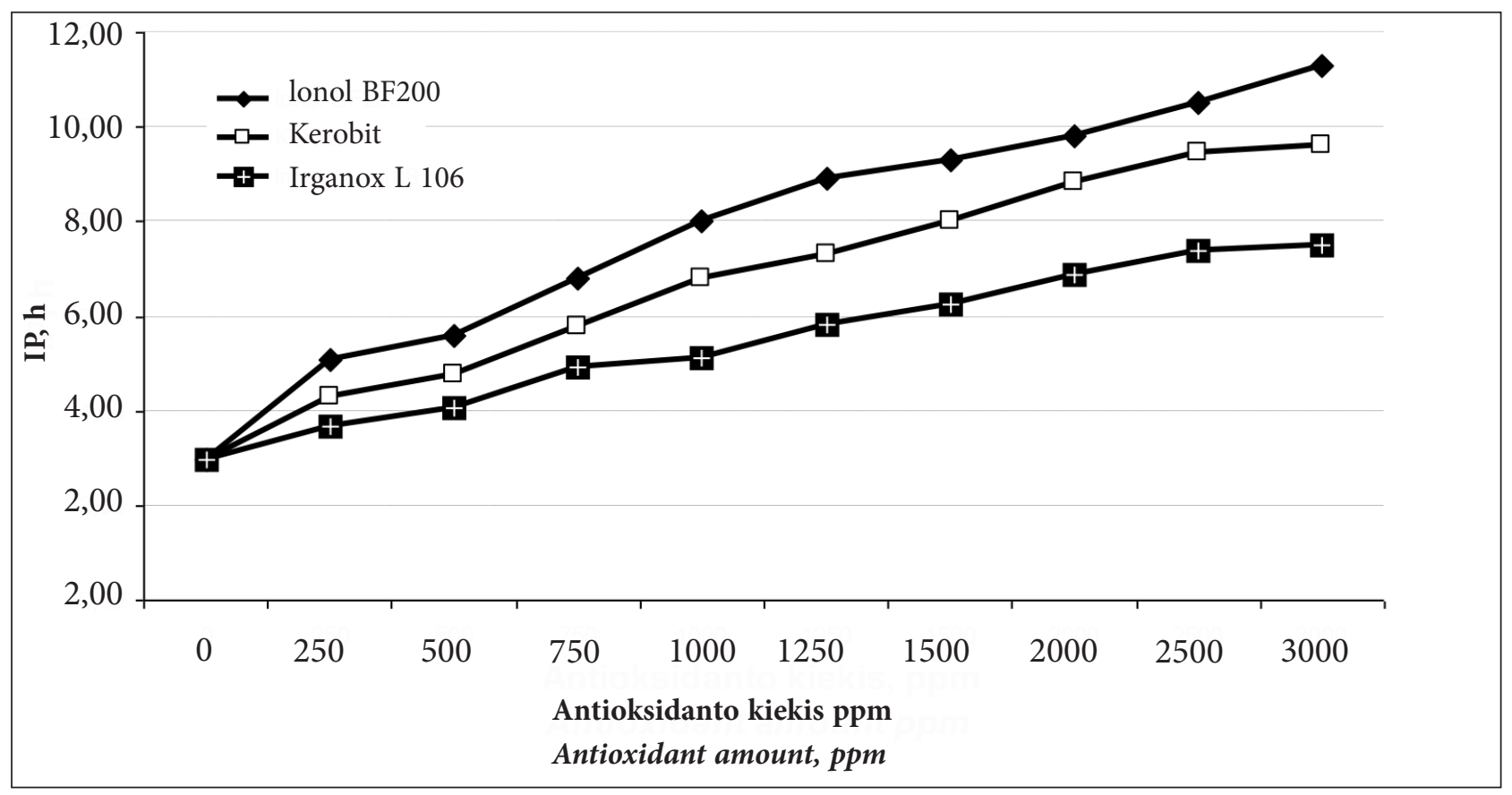

5 pav. Indukcijos periodo priklausomybè nuo antioksidantų kiekio ir rūšies

Fig. 5. The dependence of the induction period on the antioxidant amount

2 lentelè. Depresantų poveikis JRBE ribinei filtruojamumo temperatūrai (RFT)

Table 2. Depressant effects on JRBE cold filter plugging point (CFPP)

\begin{tabular}{c|ccccccc}
\hline $\begin{array}{c}\text { Depresantas } \\
\text { Depressant }\end{array}$ & \multicolumn{7}{c}{$\begin{array}{c}\text { RFT, kai depresanto koncentracija (ppm) } \\
\text { CFPP when depressant concentration (ppm) is }\end{array}$} \\
\hline & 0 & 500 & 1000 & 1500 & 2000 & 3000 & 4000 \\
\hline Infenium 485 & +3 & +3 & +3 & +1 & +1 & 0 & 0 \\
\hline Viscoplex 10-305 & +3 & +1 & +1 & 0 & -2 & -4 & -5 \\
\hline Chimec 6635 & +3 & +1 & 0 & -1 & -5 & -5 & -6 \\
\hline
\end{tabular}




\section{IŠVADOS}

Gaminant judrų aliejaus ir gyvūninès kilmès riebalų rūgščių butilesterius (JRBE) žaliavų santykis yra 1:3, efektyvus biokatalizatorius - Lipozyme TL IM. Dviejų stadijų proceso optimalios sąlygos: pirma stadija - 9 \% lipazès (aliejaus masès), aliejaus ir butanolio molinis santykis - 1:6, temperatūra $-40{ }^{\circ} \mathrm{C}$, trukmè -6 val.; antra stadija $-5 \%$ lipazès, aliejaus ir butanolio molinis santykis - 1:8, temperatūra $-40{ }^{\circ} \mathrm{C}$, sintezès trukmè -6 val. JRBE atitinka mūsų šalyje naudojamiems degalams keliamus reikalavimus, $\mathfrak{i}$ butilesterius itterpus antioksidanto Ionol BF200 (1 000 ppm) ir depresanto Chimec 6635 (2 $000 \mathrm{ppm}$ ) priedus.

\section{PADE்KA}

Autoriai dèkingi UAB „Biopolis“ už biokatalizatorių pavyzdžius.

Gauta 20160701

Priimta 20160916

\section{LITERATŪRA}

1. Antczak M. S., Kubiak A., Antczak T., Bielecki S. 2009. Enzymatic biodiesel synthesis - Key factors affecting efficiency of the process. Renewable Energy. Vol. 34. Issue 5. P. 1185-1194.

2. Berti M., Wilckens R., Fischer S., Solis A., Johnson B. 2011. Seeding date influence on camelina seed yield, yield components, and oil content in Chile. Industrial Crops and Products. Vol. 34. P. 1358-1365.

3. Haas J., Piazza G. J., Foglia T. A. 2002. Enzymatic approaches to the production of biodiesel fuels. Lipid Biotechnology. Vol. 29. P. 587-598.

4. Iso M., Chen B., Eguchi M., Kudo T., Shrestha S. 2001. Production of biodiesel fuel from triglycerides and alcohol using immobilized lipase. Journal of Molecular Catalysis B: Enzymatic. Vol. 16. P. 53-58.

5. Karavalakis G., Stournas S., Karonis D. 2010. Evaluation of the oxidation stability of diesel/ biodiesel blends. Fuel. Vol. 89(9). P. 2483-2489. DOI: 10.1016/j.fuel.2010.03.041.

6. LST EN 14103:2004. Riebaly ir aliejaus produktai. Riebalu rügščiu metilesteriai (RRME). Esteriu ir linoleno rūgšties metilesteriu kiekio nustatymas.
Vilnius: Lietuvos standartizacijos departamentas, 2004.

7. LST EN 14112:2004. Riebaly ir aliejaus produktai. Riebalu rūgščiu metilesteriai (RRME). Atsparumo oksidacijai nustatymas (pagreitintas oksidacijos metodas). Vilnius: Lietuvos standartizacijos departamentas, 2004.

8. LST EN 14214:2009. Automobiliniai degalai. Riebalu rūgščiu metilesteriai (RRME) dyzeliniams varikliams. Vilnius: Lietuvos standartizacijos departamentas, 2009.

9. LST EN 590:2009. Automobiliniai degalai. Dyzelinas. Reikalavimai ir tyrimo metodai. Vilnius: Lietuvos standartizacijos departamentas, 2009.

10. LST EN116:2015. Dyzelinis kuras ir pastatu šildymo kuras. Šalto filtro užsikimšimo temperatūros nustatymas. Vilnius: Lietuvos standartizacijos departamentas, 2015.

11. Peiretti P. G., Meineri G. 2007. Fatty acids, chemical composition and organic matter digestibility of seeds and vegetative parts of false flax (Camelina sativa L.) after different lengths of growth. Animal Feed Science and Technology. Vol. 133. Issues 3-4. P. 341-350.

12. Pfromm P. H., Amanor-Boadu V., Nelson R., Vadlani P., Madl R. 2010. Bio-butanol vs. bioethanol: A technical and economic assessment for corn and switchgrass fermented by yeast or Clostridium acetobutylicum. Biomass and Bioenergy. Vol. 34. Issue 4. P. 515-524.

13. Pullen J., Saeed K. 2014. Experimental study of the factors affecting the oxidation stability of biodiesel FAME fuels. Fuel Processing Technology. Vol. 125. P. 223-235.

14. Sendžikienè E. 2005. Žemès ūkio kilmés riebaliniu atlieku panaudojimas biodyzelino gamyboje: disertacija. $110 \mathrm{p}$.

15. Sendzikiene E., Sinkuniene D., Kazanceva I., Kazancev K. 2016. Optimization of low quality rapeseed oil transesterification with butanol by applying the response surface methodology. Renewable Energy. Vol. 87. P. 266-272.

16. Shimada Y., Watanabe Y., Sugihara A., Tominaga Y. 2002. Enzymatic alcoholysis for biodiesel fuel production and application of the reaction oil processing. Journal of Molecular Catalysis B: Enzymatic. Vol. 17. P. 133-142.

17. Shimada Y., Watanabe Y, Samukawa T., Sugihara S., Noda H., Fukuda H., Tominaga Y. 
1999. Conversion of vegetable oil to biodiesel using immobilized Candida antarctica lipase. Journal of the American Oil Chemists' Society. Vol. 76. Issue 7. P. 789-793.

18. Tashtoush G., Al-Widyan M. I., Al-Jarrah M. M. 2004. Experimental study on evaluation and optimization of conversion of waste animal fat into biodiesel. Energy Conversion and Management. Vol. 45. P. 2697-2711.

19. Tianwei T., Lu J., Chen Y., Wang F. 2009. Effect of water on methanolysis of glycerol trioleate catalyzed by immobilized lipase Candida sp. 99-125 in organic solvent system. Journal of Molecular Catalysis B: Enzymatic. Vol. 56. Issues 2-3. P. 122-125.

20. Vollmann J., Moritz T., Kargl C. 2007. Agronomic evaluation of camelina genotypes selected for seed quality characteristics. Industrial Crops and Products. Vol. 26. Issue 3. P. 270-277.

\section{Eglè Sendžikienė, Milda Gumbytė \\ BIODIESEL PRODUCTION FROM NON-FOOD FATTY WASTES}

Summary

Production of biodiesel from food crops may cause negative economic, social and environmental effects, therefore the alternatives are sought to satisfy the raw material demand for biodiesel production. The aim of research is to evaluate the possibilities of application of non-food (Camelina sati$v a)$ oil, fatty wastes of animal origin and butanol for biodiesel production by applying biotechnological methods. In order to meet the quality requirements presented in the standard, a mixture of camelina oil and animal fat in the ratio 1:3 could be used for biodiesel production. For the investigations biocatalyst - lipase Lipozyme TL IM - was selected. The optimal conditions for the production of biodiesel fuel were determined: 9\% of the lipase Lipozyme TL IM (of the oil weight); the molar ratio of oil and butanol 1:6; temperature $40^{\circ} \mathrm{C}$; duration 6 hours in the first production stage. The optimal conditions of the second stage were as follows: lipase content $5 \%$; the molar ratio of oil and butanol 1:8; temperature $40{ }^{\circ} \mathrm{C}$; duration of synthesis 6 hours. It was determined that butylesters meet the standard requirements when the additives of antioxidant Ionol BF 200 (1 000 ppm) and depressant Chimec 6635 (2000 ppm) are used.

Keywords: biodiesel, Camelina sativa oil, animal fat, biocatalyst, butanol 